saned aty
International Journal of Environmental Analytical

Chemistry

\title{
Histopathological effects of the herbicide atrazine on gills of the Brazilian endemic bivalve Diplodon expansus
}

\section{Larissa Rosa Nogarol, Ana Luiza Brossi-Garcia, Raphael Bastão de Souza \& Carmem Silvia Fontanetti}

To cite this article: Larissa Rosa Nogarol, Ana Luiza Brossi-Garcia, Raphael Bastão de Souza \& Carmem Silvia Fontanetti (2016) Histopathological effects of the herbicide atrazine on gills of the Brazilian endemic bivalve Diplodon expansus, International Journal of Environmental Analytical Chemistry, 96:4, 387-403, DOI: 10.1080/03067319.2016.1150461

To link to this article: https://doi.org/10.1080/03067319.2016.1150461

册 Published online: 21 Mar 2016.

Submit your article to this journal $\pi$

Џ Article views: 72

View Crossmark data ¿

Citing articles: 1 View citing articles $匚$ 


\title{
Histopathological effects of the herbicide atrazine on gills of the Brazilian endemic bivalve Diplodon expansus
}

\author{
Larissa Rosa Nogarol, Ana Luiza Brossi-Garcia, Raphael Bastão de Souza \\ and Carmem Silvia Fontanetti
}

UNESP, São Paulo State University, Department of Biology, Institute of Biosciences, UNESP - São Paulo State University, 13506-900 Rio Claro, SP, Brazil

\begin{abstract}
Due to their benthic filter-feeding habits and high bioaccumulation potential of metals and organic compounds, bivalve molluscs have been widely used in studies in the field and laboratory to assess the toxic effects of several compounds discharged in rivers, oceans and estuaries. However, most ecotoxicological studies use invasive exotic species, while the response of native species is poorly known. The Brazilian endemic species Diplodon expansus occurs in rivers near areas of intense agricultural activity, and atrazine is currently one of the main residues of pesticides found in water bodies of the Brazilian territory. This study was aimed at examining the toxicity of different atrazine concentrations to a Brazilian native mollusc by analysing the histology, histochemistry and ultrastructure of its gill filaments. The cells that comprise the frontal and intermediary regions of gill filaments were the most affected by the herbicide and responses associated with damage and protection were observed. The response of tissues and cells were dose-dependent. Higher concentrations of herbicide caused more severe alterations in large areas of the gills. The persistence of the alterations observed might result in severe functional problems in the gills of these animals, negatively affecting their performance and health.
\end{abstract}

\section{ARTICLE HISTORY}

Received 18 August 2015

Accepted 26 January 2016

\section{KEYWORDS}

Morphology; histochemistry; ultrastructure; agrochemical; mussel; ecotoxicology

\section{Introduction}

The herbicide atrazine has been associated with several environmental problems, as it tends to dissipate in the environment, contaminating the soil and surface and ground waters [1]. This herbicide is one of the most widely used pesticides worldwide [2], especially in regions with a predominance of sugarcane plantations, such as in southeast Brazil in the Corumbataí River Basin [3]. Because of its physical-chemical properties, atrazine is a stable compound in the environment [4,5], increasing the chances of exposure of the biota [6]. This compound can cause pathological changes in fish [7], such as oxidative stress, induction of immunotoxicity, immune organ inflammation and histopathological changes in different organs $[8,9,10]$. In fish gills were observed varied degrees of epithelial hypertrophy, oedema, necrosis, telangiectasis and epithelial 
desquamation [8]. In molluscs, atrazine can bioaccumulate in tissues [11,12] and changes behavioural patterns at environmentally relevant concentrations [13].

Bivalve molluscs exhibit several characteristics that make them good sentinel organisms, such as benthic filter-feeding habits, wide distribution, ease of collection $[14,15]$ and high bioaccumulation potential of metals and organic compounds $[11,16,17]$. Thus, these invertebrates have been broadly used in ecotoxicological studies in marine, estuarine and freshwater habitats.

Most ecotoxicological studies using bivalve molluscs in the biomonitoring of disturbed aquatic habitats or bioassays are focused on North America and Europe, especially using species of the genus Mytilus in marine habitats, as pointed out by Gregory et al. [15] and David and Fontanetti [18]. In freshwater habitats, exotic invasive species from Asia have been used, such as Dreissena polymorpha [2,19] and Corbicula fluminea $[20,21]$.

In order to improve the accuracy of ecological assays, species commonly found in the southern hemisphere have recently received more attention in the assessment of disturbed habitats in these areas, such as those conducted by Brazilian and South African research groups using the marine bivalve Perna perna $[15,16,22]$, the estuarine bivalve Mytella falcata [18,23,24], and the freshwater bivalves Anadontites trapezialis [4,11] and Diplodon fontaineanus [25].

The impact of pollutants in aquatic organisms can be assessed in different levels of biological organisation, including histopathology [26]. Histopathological analysis can provide information on the general health of the animal and changes in the tissues caused by the exposure to toxic agents $[27,28,29]$. These alterations may have an ecological significance, due to adverse or impaired effects on growth, reproduction and performance of organisms exposed to xenobiotics [29].

Among the main target organs used to examine the effects of pollutants in molluscs, gills are considered adequate for ecological assessments due to their large surface area in contact with the surrounding water contaminated by xenobiotics [30]. In general, gill filaments of bivalve molluscs consist of epithelial and endothelial cells, and mucocytes [31,32]. The morphology of gill filaments allows this organ to play different roles, such as respiration, transport of food particles and formation of a protective and lubricant layer of mucus on the epithelial surface [33,34].

Therefore, this study was aimed at examining the histology, histochemistry and ultrastructure of the gill filaments of the Brazilian endemic species Diplodon expansus, which occurs in areas of intense agricultural activity in southeast Brazil, after acute exposure to the herbicide atrazine in environmentally realistic exposure concentrations.

\section{Experimental}

\subsection{Tested compound}

Atrazine (2-chloro-4-ethylamino-6-isopropylamino-s-triazine) is a selective herbicide of the triazine group. This herbicide is classified as moderately toxic to humans (class III) and highly hazardous for the environment (class II). The concentrated suspension of the commercial product Atrazine Nortox $500 \mathrm{SC}{ }^{\circledR}$ is used in the control of weeds for 
pre-emergent and early post-emergent applications in corn, sugarcane and sorghum crops.

\subsection{Collection of animals}

Specimens of $D$. expansus (average body weight $\pm S D=14.15 \mathrm{~g} \pm 7.8$; average shell length $\pm \mathrm{DP}=4.29 \mathrm{~cm} \pm 0.84$ ) were collected in April 2010 in Ribeirão Claro, municipality of Rio Claro (S 22'24'33.1"; O 47032'25.1"), São Paulo, Brazil. In order to ensure low contamination levels at the collection site, water samples were collected according to Environmental Sanitation Technology Company [35] and Water Management Company [36] and metal and pesticide levels were quantified.

In the laboratory, the specimens were acclimated for three days in $40 \mathrm{~L}$ aquaria filled with water from an artesian well at $25^{\circ} \mathrm{C}$, constant aeration and 12 hours photoperiod. This procedure was used to minimise stress caused by collection procedures and transport of animals.

\subsection{Chemical analysis}

After collection, water samples were transported in coolers with reusable ice packs to TASQA Laboratory (Paulínia, São Paulo, Brazil), where chemical analysis were carried out.

Concentration of organic parameters (atrazine, glyphosate and 2,4-D) and inorganic compounds (aluminium, total cadmium, total lead, dissolved copper, dissolved iron, total manganese, total nickel, total silver, total zinc) established by the National Environment Council [37] were used to evaluate the quality of water samples.

Residues of atrazine and 2,4-D were quantified by the concentration of semi-volatile organic compounds with the Environmental Protection Agency - EPA 8270D method. For glyphosate, the EPA 547 method was used.

The concentration of metals in water samples was obtained based on the quantification of elements by atomic emission spectrophotometry in inductively coupled argon plasma in aqueous extract, according to the SM21 3120B method (SM21 Standard Methods for the Examination of Water and Wastewater 21th edition 2005), similar to the EPA 6010B quantification method, after acid digestion in closed system using microwave heating, following EPA 3015 for liquid samples and EPA 3052 for solid samples.

The concentrations of metals and pesticides in water samples from the collection site were compared with the maximum values allowed for freshwater bodies reported by the National Environment Council [37]. Freshwater in the Brazilian territory is classified based on the quality required for a given use. In this study, class I and II levels, for human consumption and protection of aquatic communities, were used.

The water quality patterns determined by the National Environment Council [37] establish individual limits for each compound in each class and the maximum concentrations allowed. Concentrations above the limits indicate compromised water quality for its corresponding uses. 


\subsection{Bioassay design}

Six 10-L aquaria were used: one aquarium as the control group containing water from an artesian well and five aquaria containing different concentrations of atrazine $(2,6.25$, $12.5,25$ and $50 \mu \mathrm{g} / \mathrm{L})$ obtained by diluting a stock solution $(0.5 \mathrm{~g} / \mathrm{L})$ in water. The highest concentration tested $(50 \mu \mathrm{g} / \mathrm{L})$ is twice that indicated for agricultural use, while the lowest concentration $(2 \mu \mathrm{g} / \mathrm{L})$ is the maximum allowed in freshwater bodies by Brazilian laws according to the CONAMA resolution 357 [37]. These concentrations were used to evaluate the effects of indiscriminate use of pesticides and the effect of dilution of atrazine in water bodies, similar to environmentally realistic concentrations. The bioassays were as follows:

Control: $8 \mathrm{~L}$ of artesian well water

Treatment 1: $8 \mathrm{~L}$ of artesian well water $+16 \mu \mathrm{g}$ of atrazine $(2 \mu \mathrm{g} / \mathrm{L})$

Treatment 2: $8 \mathrm{~L}$ of artesian well water $+50 \mu \mathrm{g}$ of atrazine $(6.25 \mu \mathrm{g} / \mathrm{L})$

Treatment 3: $8 \mathrm{~L}$ of artesian well water $+100 \mu \mathrm{g}$ of atrazine $(12.5 \mu \mathrm{g} / \mathrm{L})$

Treatment 4: $8 \mathrm{~L}$ of artesian well water $+200 \mu \mathrm{g}$ of atrazine $(25 \mu \mathrm{g} / \mathrm{L})$

Treatment 5: $8 \mathrm{~L}$ of artesian well water $+400 \mu \mathrm{g}$ of atrazine $(50 \mu \mathrm{g} / \mathrm{L})$

The water in aquaria was aerated continuously by an air pump. After acclimation, five animals were randomly distributed per aquarium. Animals were exposed for seven days in order to evaluate an acute response. This time of exposure has been used in previous studies with atrazine and freshwater bivalves $[2,11]$.

The experimental conditions consisted of a semi-static system with $100 \%$ of the volume changed every 24 hours, followed by addition of a freshly prepared stock solution of atrazine with distilled water, to maintain the concentration of the herbicide. The temperature was maintained between $23^{\circ} \mathrm{C}$ and $25^{\circ} \mathrm{C}$ during the exposure period.

After seven days of exposure, molluscs were anaesthetised by thermal shock in freezer and small fragments of gills were removed and fixed.

\subsection{Histology and histochemistry}

Small fragments per individual were removed from the gill located on the right of visceral mass (five individuals for each bioassay) and were fixed in aqueous Bouin solution for 24 hours; immersed in a sodium phosphate buffer solution $(\mathrm{pH}=7)$ and maintained in the refrigerator for 12 hours. Samples were then dehydrated in a crescent series of ethanol $(70 \%, 80 \%, 90 \%$ and $95 \%$,) for 20 minutes each bath, and processed for inclusion in historesin.

The material was sectioned at $5 \mu \mathrm{m}$ with a Leica RM 2245 microtome and glass knifes. Sections were hydrated in histological bath and placed in slides. After drying, sections were stained with Harris haematoxylin for 10 minutes and rinsed under tap water for 5 minutes, stained with aqueous eosin for 5 minutes and rinsed with water. After drying, slides were mounted with Canada balsam.

Histochemical methods were carried out to detect the presence of total proteins bromophenol blue [38] and polysaccharides - simultaneously staining with PAS 
(periodic acid-Schiff) and Alcian blue [39]. Slides were mounted with Canada balsam, dried and examined under a light microscope.

\subsection{Ultrastructure}

Small fragments per individual were removed from the gill located on the right of visceral mass (five individuals for each bioassay) and were fixed with $2.5 \%$ glutaraldehyde in $0.1 \mathrm{M}$ sodium cacodylate buffer at $4^{\circ} \mathrm{C}$, rinsed with sodium cacodylate buffer and post-fixed with $1 \%$ osmium tetroxide for 2 hours. The material was rinsed once more with the same buffer, immersed in $10 \%$ ethanol for 15 minutes and contrasted with $2 \%$ uranyl acetate in $10 \%$ ethanol for 4 hours. The samples were then dehydrated in a crescent series of acetone, immersed in resin:acetone solution (1:1) for 12 hours, embedded in Epon-araldite resin with catalyser for 24 hours and maintained in an oven at $70^{\circ} \mathrm{C}$ for 24 hours for resin polymerisation. The material was sectioned with an ultramicrotome, sections were placed on copper screen and contrasted with uranyl acetate and lead citrate for later examination under electron transmission microscope Philips CM 100, operated at $80 \mathrm{kV}$ [40].

\subsection{Statistical analysis}

Three histological sections with three intact filaments of each individual and 50 gill filaments per individual (five individuals for each bioassay) were selected for counting mucocytes in order to analyse alterations in frequency related to the different concentrations of atrazine. Mucocytes were classified as intact or damaged. Slides were examined under light microscope at 100x magnification. Once a visual field (sampling size) had been randomly selected, only transversal filaments sections were analysed consecutively.

The results were statistically analysed using analysis of variance (ANOVA) with the software SYSTAT 11. Normality was verified previously with the a priori Shapiro-Wilk test (SW) with significance set at $p<0.05$.

\section{Results}

\subsection{Water analysis}

The concentrations of inorganic compounds, dissolved aluminium, dissolved iron and total manganese were lower than the maximum allowed by Brazilian laws for freshwater classes I and II [37]. However, the concentrations of all organic compounds and the remaining inorganic parameters (total cadmium, total lead, dissolved copper, total nickel, total silver and total zinc) could not be determined accurately, as they were below the limits of quantification (LQ) for the method used (Table 1). The general chemical analysis indicated that the water from the collection site is adequate for the conservation of aquatic communities and human consumption after treatment, as determined for freshwater class I and II [37]. Therefore, the collected animals were not exposed to polluted water. 
Table 1. Values of organic and inorganic parameters found in water samples from the collecting sites and maximum levels allowed by Brazilian laws (CONAMA, 2005).

\begin{tabular}{lccc}
\hline Inorganic parameters & LQ & Sample & CONAMA resolution 357 \\
\hline Dissolved aluminium & 0.070 & 0.090 & 0.100 \\
Total cadmium & 0.003 & $<\mathrm{LQ}$ & 0.001 \\
Total lead & 0.030 & $<\mathrm{LQ}$ & 0.010 \\
Dissolved copper & 0.003 & $<\mathrm{LQ}$ & 0.009 \\
Dissolved iron & 0.002 & 0.200 & 0.300 \\
Total manganese & 0.002 & 0.080 & 0.100 \\
Total zinc & 0.006 & $<\mathrm{LQ}$ & 0.180 \\
Total nickel & 0.005 & $<\mathrm{LQ}$ & 0.025 \\
Total silver & 0.003 & Sample & 0.010 \\
Organic parameters & $\mathrm{LQ}$ & $<\mathrm{LQ}$ & 2 \\
Atrazine & 15 & $<\mathrm{LQ}$ & 4 \\
2,4-D & 2 & $<\mathrm{LQ}$ & 65 \\
Glyphosate & 60 & & CNAMA resolution 357 \\
\hline
\end{tabular}

$\mathrm{LQ}$, limit of quantification. Values in $\mathrm{mg} / \mathrm{L}$ for inorganic parameters and $\mu \mathrm{g} / \mathrm{L}$ for organic parameters.

\subsection{Histology and histochemistry}

All animals of the control group survived the seven-day experiment and their gill filaments exhibited intact cells and other associated structures (Figure 1A-E) as described for the species [40].

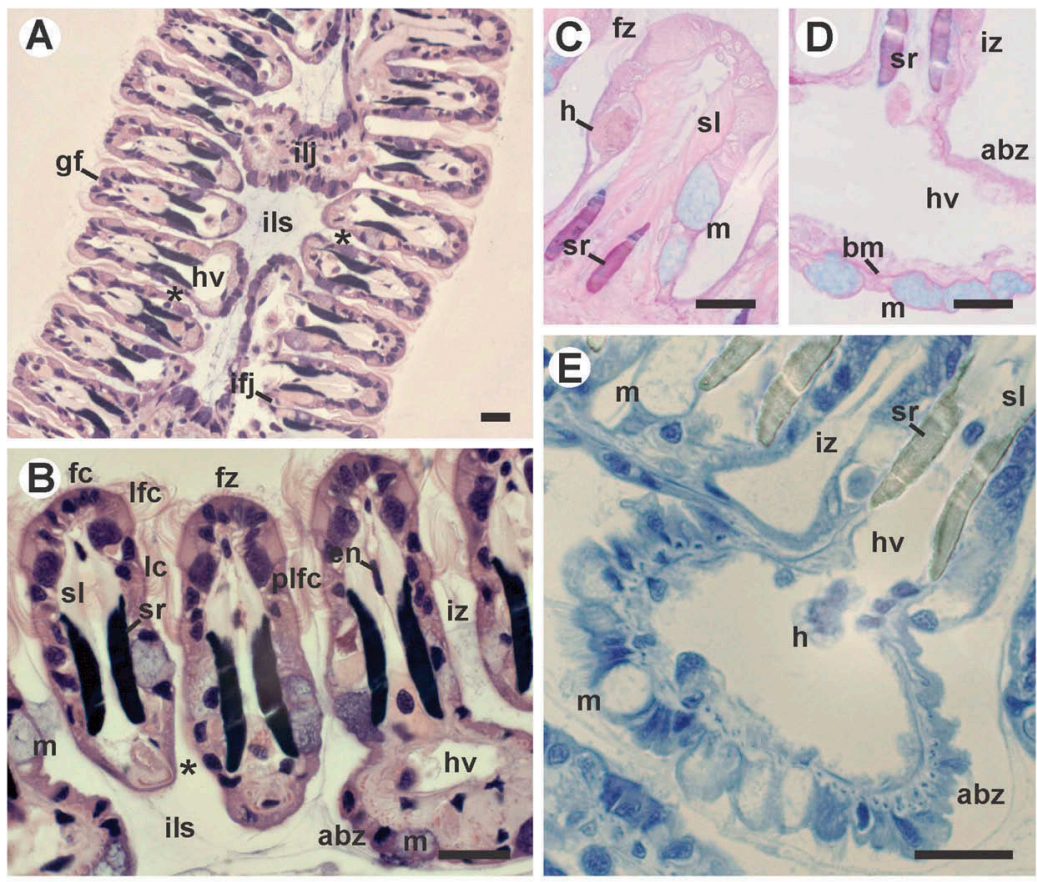

Figure 1. Gill filaments of $D$. expansus exposed to control group stained with haematoxylin and eosin (A, B), simultaneous PAS and Alcian blue (C, D), and bromophenol blue (E). Note the intact cells and other associated structures exhibited by the gills filaments.

gf, gill filament; ifj, interfilamentary junction; ilj, interlamellar junction; hv, haemolymph vessel; ils, interlamellar space; *, ostia; fz, frontal zone; iz, intermediary zone; abz, abfrontal zone; fc, frontal cilia; Ifc, latero-frontal cilia; Ic, lateral cilia; plfc, post-latero frontal cell; sr, skeletal rod; sl, skeletal loop; m, mucocyte; en, endothelium; bm, basal membrane; h, haemocyte. Scale bars $=20 \mu \mathrm{m}$. 
All animals exposed to different concentrations of atrazine survived the seven-day experiments. All concentrations of atrazine induced histopathological alterations in the gill filaments of the bivalve $D$. expansus. Alterations were observed in the frontal and intermediary zone of gill filaments, and were more severe and frequent in animals exposed to higher concentrations of the herbicide (treatments 4 and 5) and less severe and rare in those exposed to lower concentrations (treatments 1, 2 and 3).

In individuals of treatment 1 , adherence of epithelial cells (* in Figure $2 \mathrm{~A}$ ) and lateral fusion of gill filaments (Figure 2B, C) were observed. Individuals of treatment 2, 3 and 4 exhibited dilation of the intercellular space in the frontal zone (white arrows in Figures $2 \mathrm{E}$ and $3 \mathrm{~A}$ ). Haemocytes infiltration was observed throughout the structure (Figure $2 \mathrm{~A}$ ).

In the intermediary region of gill filaments of these individuals, total loss of integrity of gill filaments was observed (Figure 3B, C).

In individuals of treatment 5, haemocytes (Figure 3F) and distension of the frontal cells (Figure 3D, F and G) were observed. The intermediary zone exhibited ruptured mucocytes (Figure 3G); haemocytes crossing the epithelium were observed (Figure 3D). Gill filaments with total loss of integrity (Figure $3 \mathrm{H}$ ) were also found in this treatment group.

The histopathological alterations and their frequency in each treatment group are presented in Table 2. In the histochemical analysis, the gill filaments of animals exposed exhibited the same pattern described for the control group.

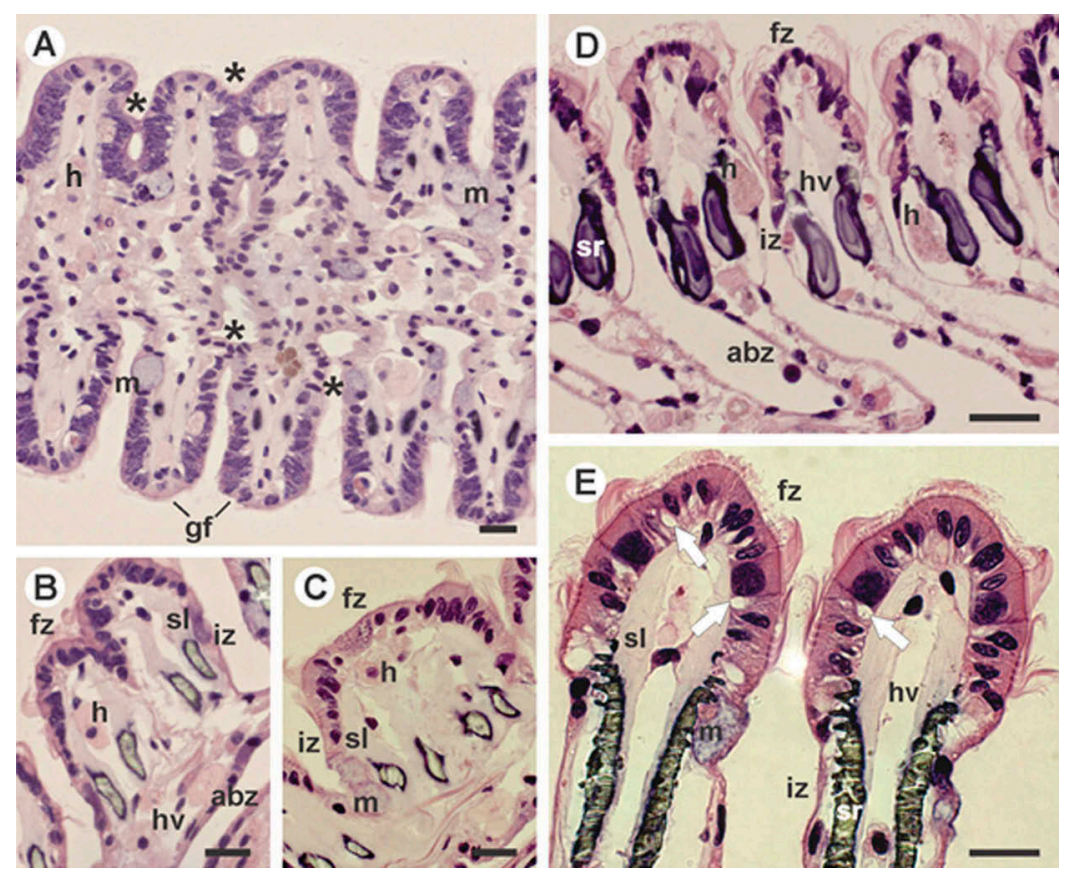

Figure 2. Gill filaments of $D$. expansus exposed to treatment $1(A-C)$ and treatments 2 and $3(D, E)$ stained with haematoxylin and eosin. Morphological alterations, such as adherence of epithelial cells (* in A), lateral fusion of gills filaments (in detail in B and C) and dilation of the intercellular space (arrows in $\mathrm{E}$ ) can be observed in the intermediary zone and in the frontal zone.

gf, gill filament; $m$, mucocyte; $f z$, frontal zone; iz, intermediary zone; abz, abfrontal zone; hv, haemolymph vessel; sr, skeletal rod; sl, skeletal loop; h, haemocyte. Scale bars $=20 \mu \mathrm{m}$. 


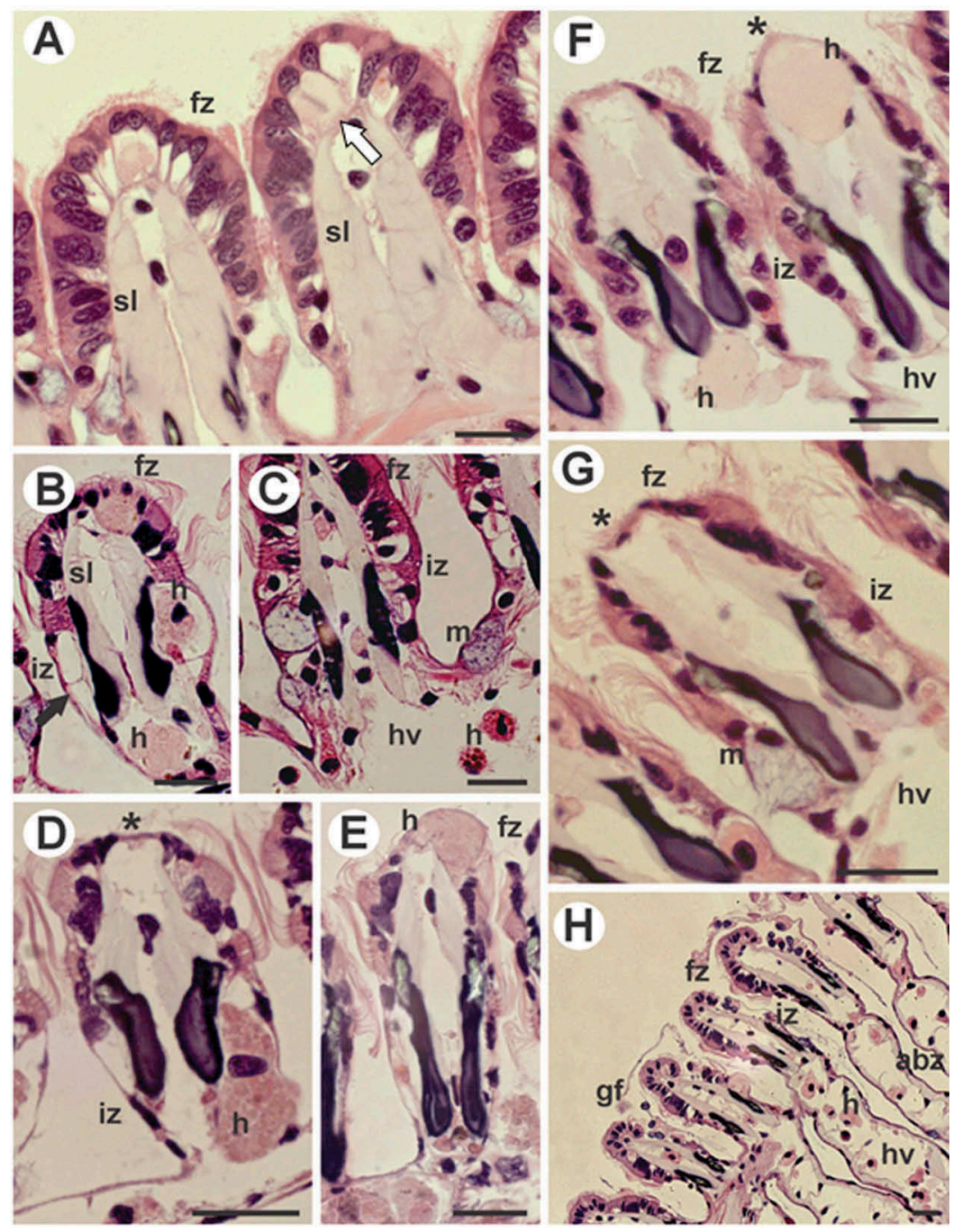

Figure 3. Gill filaments of $D$. expansus exposed to treatments $4(A-C)$ and $5(D-H)$, the highest concentrations used, stained with haematoxylin and eosin. Dilation of the intercellular space (white arrow) was present in the frontal zone of gill filaments. In the intermediary region was observed haemocytes crossing the epithelium ( $B$ and $D$ ).

$\mathrm{fz}$, frontal zone; iz, intermediary zone; abz, abfrontal zone; sl, skeletal loop; h, haemocyte; hv, haemolymph vessel; m, mucocyte; ${ }^{*}$, distension of epithelial cells. Scale bars $=20 \mu \mathrm{m}$.

\subsection{Ultrastructure}

The ultrastructural analysis of the control group gills revealed microvilli on the free surface of the epithelial cells that comprise the gill filaments of the bivalve $D$. expansus (Figure 4A, G). Epithelial cells were united by junction complex formed by adherens and septate junctions (Figures. $4 \mathrm{H}, \mathrm{I}$ ). 
Table 2. Histopathological alterations in the gill filaments of the bivalve $D$. expansus after acute exposure to the herbicide atrazine.

\begin{tabular}{lcccccc}
\hline \multirow{2}{*}{ Effects } & \multicolumn{5}{c}{ Bioassays } \\
\cline { 2 - 6 } & Treatment 1 & Treatment 2 & Treatment 3 & Treatment 4 & Treatment 5 \\
\hline Epithelial adhesion & + & - & - & - & - \\
Filament fusion & + & - & - & - & - \\
Flattening of the epithelium (FZ) & - & - & - & + & ++ \\
Oedema & - & - & + & ++ & ++ \\
Epithelial detachment (IZ) & - & + & ++ & - & + \\
Dilation of the intercellular space & - & - & - & ++ & +++ \\
Loss of the integrity of the filament & - & - & + & + \\
\hline
\end{tabular}

- absence of histopathological alterations; + rare alterations; ++ relatively common alterations; +++ alterations frequently observed in extensive areas of gill filaments.

FZ Frontal Zone; IZ Intermediary Zone.

In the frontal zone, frontal cells exhibited well-developed Golgi apparatus and electron-lucent mitochondria located mainly near basal bodies, where cilia were inserted (Figure 4A). A few electron-dense vesicles were dispersed in the cytosol (Figure 4B).

In the apical domain of latero-frontal cells, cilia (black arrows in Figure 4C) were attached at the basal bodies and arranged in a system of rootlets (white arrows in Figure 4 C). Ciliary rootlets exhibited striated structures that extended from the basal body until the basal domain of cells.

The postlateral-frontal cells exhibited well-developed endoplasmic reticulum and Golgi complex, and few electron-dense vesicles dispersed in the cytosol (Figure 4D). Several mitochondria were observed in electron-dense lateral cells (Figure 4E). The cytosol of mucocytes present in the intermediary and abfrontal zones was filled by electron-lucent secretion vesicles (Figure $4 \mathrm{~F}, \mathrm{~J}$ ).

The cells and other structures comprising the gill filaments of animals of treatment 1 remained intact. In the frontal cells of individuals of treatments 2 and 3, autophagic vacuoles and electron-dense vesicles, located mainly in the apical domain, were more abundant. Cell junctions remained intact (Figure 5A).

In treatment 4 were observed infiltration dilation of intercellular space and loss of cell integrity in the frontal (Figure 5B, C) and intermediary (Figure 5D) zones of the gill filament. An increased number of mitochondria were observed near the free surface of mucocytes (Figure 5E).

In treatment 5, cells of the frontal zone of the gill filament exhibited electron-dense cytoplasm (Figure 5F). Vacuoles were observed in the cytosol of latero-frontal cells (Figure 5G). The plasma membrane of mucocytes lost their integrity in the intermediary (Figure $5 \mathrm{H}$ ) and abfrontal zones (Figure 5I).

\subsection{Statistical analysis}

The number of mucocytes exhibited a normal distribution $(p<0.05)$. Therefore, the parametric test ANOVA was applied. No significant differences were found regarding the number of mucocytes $\left(R^{2}=0.077 ; \mathrm{GL}=5 ; p=0.907\right)$ and the number of ruptured mucocytes $\left(R^{2}=0,323 ; \mathrm{GL}=5 ; p=0,182\right)$ between the control and treatment groups. 

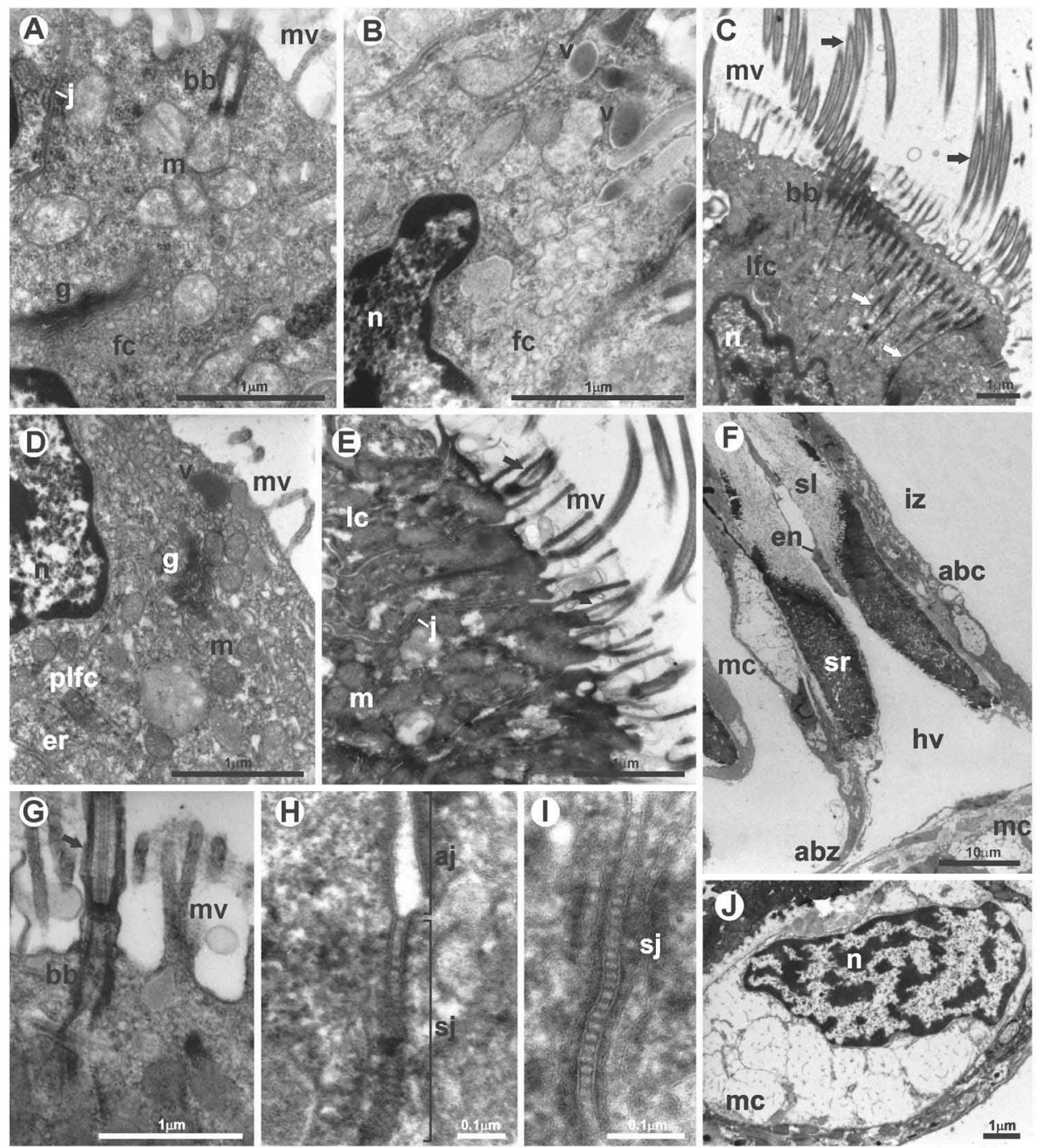

Figure 4. Electron micrographs of cells present in frontal $(A-E)$, intermediary and abfrontal $(F, J)$ zones of gill filaments of $D$. expansus and details of microvilli $(G)$ and cell junctions $(H, I)$ exposed to control group.

mv, microvilli; v, vesicle; $j$, cell junction; aj, adherens junction; sj, septate junction; bb, basal body; $n$, nucleus; $\mathrm{m}$, mitochondria; er, endoplasmic reticulum; g, Golgi complex; fc, frontal cell; lfc, laterofrontal cell; plfc, post-latero frontal cell; lc, lateral cell; abc, absorptive cells; en, endothelium; hv, haemolymph vessel; iz, intermediary zone; abz, abfrontal zone; sl, skeletal loop; sr, skeletal rod; mc, mucocyte; black arrow - cilia; white arrow - rootlets.

The average number of mucocytes found in animals of treatment 5 was 1.14 times higher than that of the control group (Table 3). The highest averages of ruptured mucocytes (Table 3) were obtained in animals of treatments 4 and 5. 

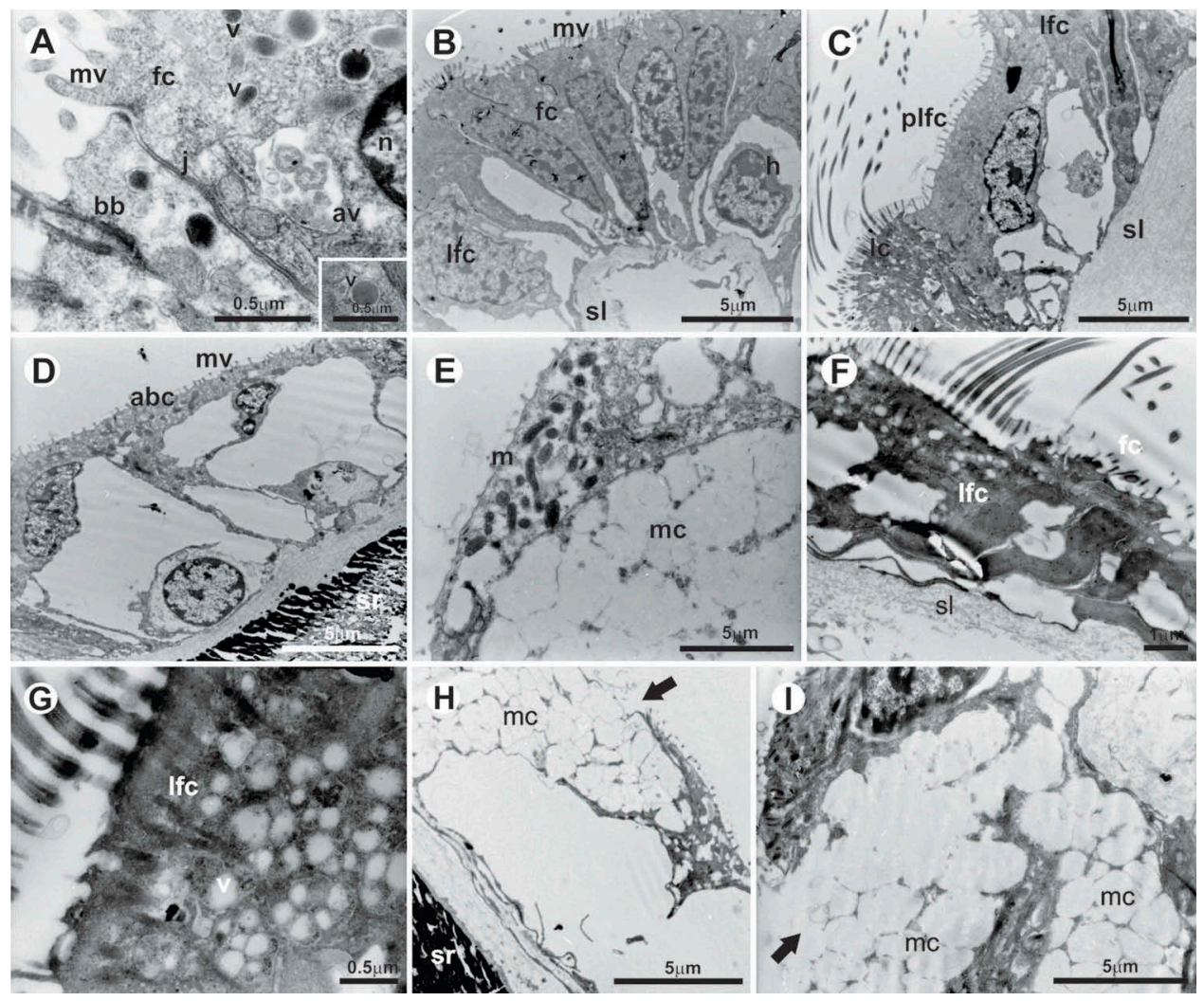

Figure 5. Electron micrographs of cells present in frontal $(A-C, F, G)$, intermediary $(D, E, H)$ and abfrontal (I) regions of gill filaments of $D$. expansus exposed to treatments 2 and $3(A), 4(B-E)$ and $5(F-I)$. Note the ruptured membrane (arrows) of the mucocyte and the abundance of mitochondria and vacuoles.

$\mathrm{mv}$, microvilli; $\mathrm{v}$, vesicle; $\mathrm{j}$, cell junction; av, autophagic vacuole; bb, basal body; $\mathrm{n}$, nucleus; $\mathrm{m}$, mitochondria; fc, frontal cell; Ifc, latero-frontal cell; plfc, post-latero frontal cell; Ic, lateral cell; abc, absorptive cells; h, haemocyte; sl, skeletal loop; sr, skeletal rod; mc, mucocyte.

Table 3. Average and standard deviation of total and ruptured mucocytes in the epithelium of 50 gill filaments of $D$. expansus ( $n=5$ ).

\begin{tabular}{|c|c|c|c|c|c|c|c|c|}
\hline \multirow[b]{2}{*}{ Groups } & \multicolumn{4}{|c|}{ Mucocytes } & \multicolumn{4}{|c|}{ Ruptured mucocytes } \\
\hline & Min & Max & Average & SD & Min & Max & Average & SD \\
\hline$C$ & 44 & 119 & 75.50 & 33.27 & 7 & 27 & 14.50 & 9.00 \\
\hline T1 & 35 & 126 & 79.50 & 42.60 & 7 & 24 & 14.25 & 7.50 \\
\hline $\mathrm{T} 2$ & 65 & 82 & 72.00 & 7.16 & 5 & 23 & 10.50 & 8.38 \\
\hline T3 & 57 & 102 & 76.25 & 18.90 & 10 & 16 & 13.25 & 2.75 \\
\hline T4 & 47 & 88 & 64.75 & 17.72 & 19 & 26 & 22.00 & 3.55 \\
\hline T5 & 69 & 126 & 86.75 & 26.48 & 11 & 28 & 20.75 & 7.50 \\
\hline
\end{tabular}

SD, standard deviation; $C$, control; T1, treatment $1 ; \mathrm{T} 2$, treatment $2 ; \mathrm{T} 3$, treatment 3 ; $\mathrm{T} 4$, treatment 4 ; $\mathrm{T} 5$, treatment 5. $p<0.05$.

\section{Discussion}

The exposure of the bivalve $D$. expansus to atrazine induced significant alterations in the morphology of the gill filaments. The level and frequency of damage was dose dependent. Lower concentrations of the herbicides caused few morphological changes, while 
higher concentrations resulted in extensive altered areas of the gill filaments of $D$. expansus. Similar results were obtained by Yang et al. [5] based on a morphological analysis of gills of the fish Gobiocypris rarus exposed to environmentally relevant concentrations of this herbicide. According to these authors, the lesions were more severe as higher the concentration of atrazine, with histopathological alterations found in individuals exposed to concentrations equal or above $10 \mu \mathrm{g} / \mathrm{L}$.

The exposure to environmental pollutants can induce two main types of alterations at the tissue and cell level: changes that indicate damage and those that show the presence and action of protection or defence mechanisms [41,42]. Defence mechanisms require considerable amounts of energy to be continuously active. Thus, responses associated with higher energy use are also observed under environmentally stressful conditions [42]. Alterations indicating damage were characterised by dilation of the intercellular space, cytoplasmic condensation and vacuolation. The main defence alterations observed were filament fusion, infiltration of haemocytes in the epithelium and increase in the number of autophagic vacuoles. The response associated with energy use was the increased number of mitochondria in mucocytes.

The fusion of gill filaments has been reported in bivalve molluscs exposed to toxic agents $[26,29,32,43]$. The corresponding response in fish is the fusion of secondary lamellae, commonly observed in individuals exposed to different pollutants, including the herbicide atrazine $[5,44,45]$. Filament fusion can occur in the intermediary and abfrontal zones of gill filaments of bivalve molluscs. Filament fusion in the intermediary zone is usually termed lateral fusion [43] while that located in the abfrontal zone is termed lamellar fusion [26,32]. In bivalve molluscs, some authors believe that this alteration is the result of errors during the regeneration of the gill epithelium [26,32].

In the present study, the lateral fusion of gill filaments probably occurred due to the increase in adherence of epithelial cells. These responses are associated with the attempt to reduce the surface area between the epithelium of gill filaments and the toxic agent in the water. The fusion of gill filaments, however, also decreases the surface area for gas exchanges and changes the number and arrangement of cilia. Thus, if this morphological change becomes more extensive, respiration and food uptake may be compromised, negatively influencing the health, survival and growth of animals.

In invertebrates, haemocytes play an important role in the defence of the organism through several processes, such as inflammation. The number of these specialised cells may increase in tissues damaged after exposure to a toxic agent [46], acting in the removal of toxins [47] and the reabsorption of the damaged epithelium [24]. Haemocytes can leave the haemolymph vessels and infiltrate in different organs, as observed in the gill filaments of bivalve molluscs $[24,26]$ and the midgut of diplopods $[47,48,49]$. Haemocytes were observed over the tissue, probably acting as a defence mechanism

In bivalve molluscs, the increase in mucus secretions is a very common response to the exposure to a toxic agent $[18,23,40]$. This response is usually associated with protection or defence mechanisms, as mucus might dilute toxins [42], thus removing toxic agents previously absorbed [50] and creating a barrier to prevent the entrance of toxic agents in damaged cells [24]. David and Fontanetti [23] examined whether the number of mucous cells could be used as an efficient pollution biomarker in estuarine bivalves. These authors observed that the number of cells secreting mucus increased 
according to the level of pollution at the site of collection of animals. Animals from more heavily impacted sites of the Santos Estuary (São Paulo, Brazil) exhibited more mucous cells in the gill filaments. Gregory et al. [15] also reported an increase in the number of mucocytes in the abfrontal region of gill filaments of bivalves after 16 days of exposure to mercury. After the recovery period, cells returned to pre-exposure levels.

In the present study no significant differences were found in the number of mucocytes between the control and treatment groups. However, dense layers of mucus were observed in the surface of gill filaments of the individuals exposed to higher concentrations of atrazine [51]. Thus, the increase in mucus on the surface of gill filaments of the study species is not associated with the number or integrity of mucocytes. Mucusproducing cells might be hyperactive in order to produce higher amounts of mucus to protect gill filaments. This hyperactivity requires higher levels of energy, which explains the presence of more mitochondria in mucocytes.

The increase in autophagic vacuoles and electron-dense vesicles was a very evident response in frontal cells of animals exposed to lower concentrations of atrazine. Autophagic vacuoles present in the cytosol of cells acted in the degradation and recycling of old or damaged cell components [52,53]. Therefore, higher quantities of autophagic vacuoles might indicate the presence of many organelles damaged by the action of the herbicide. In the attempt to maintain viability, the cell isolates damaged components and initiates the process of intracellular digestion. However, some cell remnants from these vacuoles might not be completely digested, such as lipofuscin granules [54].

Therefore, the electron-dense granules frequently found in the cytosol of these cells might be lipofuscin granules. Lipofuscin is a by-product of the oxidative attack on proteins and lipids and can accumulate in lysosomes [55]. Some authors describe these granules as participants of detoxification mechanisms, as metal binding sites $[43,56,57]$. As a result, the increase in the number of lipofuscin granules in different tissues of bivalve molluscs has been used as a stress biomarker [26,58].

In some cases, such as exposure to higher concentrations of toxic agents, defence mechanisms are insufficient to maintain the integrity of cells and tissues, resulting in responses indicating damage. One of these responses found in the epithelial cells that comprise the gill filaments of the bivalve $D$. expansus was the dilation of the intercellular space. The same response was observed in the gill filaments of bivalves exposed to mercury [30] and in the midgut epithelium of diplopods exposed to soil contaminated with metals and polycyclic hydrocarbons [47].

Kumar et al. [54] reported that intercellular space dilation is associated with modifications in the plasma membrane as a result of the loss of stability of junction complexes. However, in animals from treatments 2 and 3, the ultrastructure analysis indicated that cell junctions were intact. Sunila [59] exposed the bivalve Mytilus edulis to different environmental pollutants such as metals and pesticides. The organic toxic agents induced shrinkage and separation of the plasma membrane of cells of gill filaments. Thus, intercellular space dilation in animals exposed to atrazine might be a consequence of cell atrophy. This was supported by the increased number of autophagic vacuoles in the cytosol of these cells, as previously described, which is frequently observed in cells undergoing atrophy [54]. 
Cytoplasmic condensation was also observed in animals exposed to higher concentrations of atrazine. A similar response was also reported for terrestrial invertebrates exposed to different metals $[60,61]$ and fish after exposure to mercury, copper and benzopyrene [62-64]. This response is usually accompanied by a reduction in the number of organelles and changes in cell osmolarity [61], and may result in a decrease in cell volume and consequently dilation of the intercellular space [60]. The latero-frontal cells of $D$. expansus exhibited condensed cytoplasm with vacuoles. These responses indicate that these cells sustained irreversible damage and are undergoing cell death. Cytoplasmic vacuolation is a typical response of cell death after severe stress, such as the exposure to a toxic agent [65]. According to Zupan and Kalafatic [66], low atrazine concentration can cause vacuolation of hepatocytes, although gill cells are not affected. Results obtained by Liu [67] suggest that low atrazine concentration can induce fish cell death through apoptosis and high concentration can induce necrosis. Cytoplasm condensation suggests that the cytoplasmic components may be damaged and non-viable.

The filtering of particles present in the circulating water is one of the main roles of latero-frontal cells [68]. These cells exhibit specialised cilia that act as nets to capture food particles [69]. Therefore, damage to these cells can decrease the filtering rate and consequently food intake, as observed for the mollusc $P$. perna exposed to mercury for two days [15].

The flattening of frontal cells and loss of cilia were observed in animals exposed to the highest concentration of atrazine. The exposure to mercury for two and four days induced similar responses in the bivalve $P$. perna [15]. The authors reported that throughout the days of exposure, alterations became less frequent and after the recovery period, were no longer observed. Nogarol et al. [51] observed disorganisation and loss of frontal cilia of gill filaments of $D$. expansus exposed to the same conditions described in the present study. These authors suggested a higher sensitivity of frontal ciliated cells, as confirmed in our study by the observation of flat frontal cells and oedemas.

\section{Conclusions}

The results clearly indicate that sub-lethal concentrations of atrazine have adverse effects on the gill filaments of the study species. This herbicide apparently induces dose-dependent alterations. Some of these alterations, such as filament fusion and cytoplasmic condensation, might result in severe functional impairment, compromising the health and performance of animals exposed for long periods to this herbicide.

\section{Acknowledgements}

The authors thank Dr Wagner Eustáquio Paiva Avelar and Dr Cláudia Tasso Callil for the identification of species, Mônika lamonte, Antonio Teruyoshi Yabuki and Gerson Mello de Souza for technical support, Marcos Perdiza for assistance in the collection of animals, Dr Tamaris Gimenez Pinheiro for assistance with statistical analysis, the biologists MSc Ana Claudia de Castro Marcato and Dr Cintya Aparecida Christofoletti for assistance during experiments. 


\section{Conflict of Interest}

The authors declare that they have no conflict of interest.

\section{Disclosure statement}

No potential conflict of interest was reported by the authors.

\section{Funding}

This work was supported by The State of São Paulo Research Foundation (FAPESP) [grant numbers 2009/12489-9 and 2012/50197-2].

\section{References}

[1] S.M. Sanches, C.H.T.P. Silva, S.X. Campos, E.M. Vieira and P.R. Ecotoxicol, E Meio. Ambiente. 13, 53 (2003).

[2] I. Zupan and M. Kalafatic, Bull. Environ. Contam. Toxicol. 70, 688 (2003). doi:10.1007/s00128003-0039-8.

[3] E.D. Armas, R.T.R. Monteiro, A.V. Amâncio, R.M.L. Correa and M.A. Guercio, Quim. Nova. 28, 975 (2005). doi:10.1590/S0100-40422005000600008.

[4] A.E. Jacomini, P.S. Bonato and W.E.P. Avelar, J. Liq. Chrom. Relat. Tech. 26, 1885 (2003). doi:10.1081/JLC-120021757.

[5] L. Yang, J. Zha, W. Li, Z. Li and Z. Wang, Aquat. Toxicol. 97, 204 (2010). doi:10.1016/j. aquatox.2009.09.005.

[6] K.R. Solomon, J.A. Carr, L.H. Du Preez, J.P. Giesy, R.J. Kendall, E.E. Smith and G.J.V. Der Kraak, Crit. Rev. Toxicol. 38, 772 (2008). doi:10.1080/10408440802116496.

[7] K. Jayachandran and K. Pugazhendy, Am-Euras J. Sci. Res. 4, 219 (2009).

[8] H. Xing, S. Li, Z. Wang, X. Gao, S. Xu and X. Wang, Pestic. Biochem. Physiol. 103, 74 (2012). doi:10.1016/j.pestbp.2012.03.007.

[9] D. Chen, Z. Zhang, H. Yao, Y. Cao, H. Xing and S. Xu, Pestic. Biochem. Physiol. 8, 114 (2014).

[10] X. Wang, H. Xing, Y. Jiang, H. Wu, G. Sun, Q. Xu and S. Xu, Food Chem. Toxicol. 62, 148 (2013). doi:10.1016/j.fct.2013.08.044.

[11] A.E. Jacomini, W.E.P. Avelar, A.S. Martinês and P.S. Bonato, Arch. Environ. Contam. Toxicol. 51, 387 (2010). doi:10.1007/s00244-005-0238-x.

[12] T. Thitiphuree, J. Kitana, P. Varanusupakul and N. Kitana, Environment. Asia 6, 13 (2013).

[13] K. Flynn, M.B. Wedin, J.A. Bonventre, M. Dillon-White, J. Hines, B.S. Weeks, C. André, M.P. Schreibman and F. Gagné, J. Toxicol. Environ. Health. 76, 1168 (2013). doi:10.1080/ 15287394.2013.845865.

[14] M.H. Depledge, The ecotoxicological significance of genotoxicity in marine invertebrates. Mutat Res 399, 109 (1998). doi:10.1016/S0027-5107(97)00270-4.

[15] M.A. Gregory, D.J. Marshal, R.C. George, A. Anandraj and T.P. Cclurg, Mar. Pollut. Bull. 45, 114 (2002). doi:10.1016/S0025-326X(01)00325-3.

[16] M.A. Gregory, R.C. George, D.J. Marshal, A. Anandraj and T.P. Mcclurg, Mar. Pollut. Bull. 39, 116 (1999). doi:10.1016/S0025-326X(99)00119-8.

[17] T.J. Naimo, A review of the effects of heavy metals on freshwater mussels. Ecotoxicology 4, 341 (1995). doi:10.1007/BF00118870.

[18] J.A.O. David and C.S. Fontanetti, Braz. J. Morphol. Sci. 22, 203 (2005).

[19] P. Mantecca, G. Vailati and R. Bacchetta, Histol Histopathol. 21, 829 (2006).

[20] G.L. Peltier, J.L. Meyer, C.H. Jagoe, A. William and W.A. Hopkins, Environ. Pollut. 154, 283 (2008). doi:10.1016/j.envpol.2007.10.004. 
[21] O. Simon, M. Floriani, I. Cavalie, V. Camilleri, C. Adam, R. Gilbin and J. Garnier-Laplace, J. Environ. Radioct. 102, 766 (2011). doi:10.1016/j.jenvrad.2011.04.004.

[22] D.M.S. Abessa, L.P. Zaroni, E.C.P.M. Sousa, M.R. Garparro, C.D.S. Pereira, B.R.F. Rachid, M. Depledge and R.S. King, Braz. Arch. Biol. Technol. 48, 217 (2005). doi:10.1590/S151689132005000200008.

[23] J.A.O. David and C.S. Fontanetti, Water Air Soil Pollut. 200, 1 (2009). doi:10.1007/s11270-0090009-9.

[24] J.A.O. David, R.B. Salaroli and C.S. Fontanetti, Micron 39, 129 (2008).

[25] A.E. Jacomini, P.B. Camargo, W.E.P. Avelar and P.S. Bonato, Arch. Environ. Contam. Toxicol. 60, 452 (2011). doi:10.1007/s00244-010-9552-z.

[26] F.M. Akaishi, S.D. St-Jean, F. Bishay, J. Clarke, I.S. Rabitto and C.A.O. Ribeiro, Aquatic Toxicol. 82, 1 (2007). doi:10.1016/j.aquatox.2007.01.008.

[27] C.S. Fontanetti, C.A. Christofoletti, T.G. Pinheiro, T.S. Souza and J. Pedro-Escher, in Microscopy: Science, Technology, Applications and Education, edited by A. Méndez-Vilas and J. Días (Formatex Research Center, Badajoz, 2010).

[28] C.S. Fontanetti, T.S. Souza and C.A. Christofoletti, in Sustainable Water Management in the Tropics and Subtropics - Cases Study in Brazil, edited by C. Bilibio, O. Hensel and J. Selbach (UNIPAMPA/UNIKASSEL, Brazil/Germany, 2012).

[29] I. Sunila, Ann. Zool. Fenn. 24, 55 (1987).

[30] M. Bigas, M. Durfort and M. Poquet, Tissue \& Cell 33, 178 (2001). doi:10.1054/tice.2000.0169.

[31] J.A.O. David, R.B. Salaroli and C.S. Fontanetti, Micron 39, 329 (2008). doi:10.1016/j. micron.2007.06.002.

[32] I. Sunila, J. Invertebr. Pathol. 47, 125 (1986). doi:10.1016/0022-2011(86)90040-6.

[33] S.C. Dufour and P.G. Beninger, M. Biol. 138, 295 (2001). doi:10.1007/s002270000466.

[34] A. Gómez-Mendikute, M. Elizondo, P. Venier and M.P. Cajaraville, Cell Tissue Res. 321, 131 (2005). doi:10.1007/s00441-005-1093-9.

[35] CETESB - Companhia Ambiental do Estado de São Paulo, Guia De Coleta E Preservação De Amostras De Água (CETESB, São Paulo, 1987).

[36] COGERH - Companhia de Gestão dos Recursos Hídricos Recomendações e cuidados na coleta de amostras de água, Informe Técnico N.02 (COGERH, Fortaleza, 2001).

[37] CONAMA Conselho Nacional do Meio Ambiente/Ministério do Meio . Resolução No. 357 de 17 de março deA. 2005. <http://www.mma.gov.br/port/conama/legiano1.cfm?codlegitipo= $3 \& a n o=2005>$.

[38] A.G.E. Pearse, Histochemical: Theoretical and Applied (Churchill Livingstone, Edinburgh, 1985), p. 624.

[39] L.C. Junqueira and L.M.M.S. Junqueira, Técnicas Básicas De Citologia E Histologia (Livraria Editora Santos, São Paulo, 1983).

[40] L.R. Nogarol, A.L. Brossi-Garcia, J.A.O. David and C.S. Fontanetti, Microsc. Microanal. 18, 1450 (2012). doi:10.1017/S1431927612013992.

[41] R.S. Parashar and T.K. Banerjee, Vet. Arch. 72, 167 (2002).

[42] R. Triebskorn, I.F. Henderson, A. Martin and H.R. Köhler, BCPC Proceedings. 66, 65 (1996).

[43] G.P. Domouhtsidou and V.K. Dimitriadis, Arch. Environ. Contam. Toxicol. 38, 472 (2000). doi:10.1007/s002449910062.

[44] K.B. Olurin, E.A.A. Olojo, G.O. Mbaka and A.T. Akindele, Afr. J. Biotechnol. 5, 2480 (2006).

[45] A.G. Yasser and M.D. Naser, Environ. Monit. Assess. 181, 175 (2011). doi:10.1007/s10661-0101822-8.

[46] D.G. Perez and C.S. Fontanetti, Environ. Monit. Assess. 177, 437 (2011). doi:10.1007/s10661010-1645-7.

[47] T.S. Souza and C.S. Fontanetti, Ecotoxicol Environ. Safe 74 (10), (2011). doi:10.1016/j. ecoenv.2010.09.009.

[48] J.A.P. Godoy and C.S. Fontanetti, Water Air. Soil. Pollut. 210, 389 (2010). doi:10.1007/s11270009-0261-z.

[49] L.R. Nogarol and C.S. Fontanetti, Micron. 41, 239 (2010). doi:10.1016/j.micron.2009.10.009.

[50] P.W.C. Sze and S.Y. Lee, Mar. Pollut. Bull. 31, 390 (1995). doi:10.1016/0025-326X(95)00140-I. 
[51] L.R. Nogarol, A.L. Brossi-Garcia and C.S. Fontanetti, Microsc. Res. Tech. 75, 807 (2012). doi:10.1002/jemt.21130.

[52] M.T.V. Azeredo-Oliveira and H.F. Carvalho, in A Célula, edited by H.F. Carvalho and S.M. Recco-Pimentel (Manole, Barueri, Brasil, 2007).

[53] P. lanella and M.M. Itoyama, Rev. Unorp. 5, 63 (2006).

[54] V. Kumar, R.S. Cotran and S.L. Robbins, Patologia Básica (Guanabara Koogan, Rio de Janeiro, 1983).

[55] M.N. Moore, J.I. Allen and P. Somerfield, Mar. Environ. Res. 62, 420 (2006). doi:10.1016/j. marenvres.2006.04.055.

[56] S.G. George, Comp. Biochem. Physiol. 76, 53 (1983). doi:10.1016/0742-8413(83)90043-9.

[57] A. Viarengo and J.A. Nott, Biochem. Physiol. 104C, 355 (1993). doi:10.1016/0742-8413(93) 90001-2.

[58] I. Zorita, M. Ortiz-Zarragoitia, M. Soto and M.P. Cajaraville, Aquat. Toxicol. 78, 109 (2006). doi:10.1016/j.aquatox.2006.02.032.

[59] I. Sunila, J. Invertebr. Pathol. 52, 137 (1988). doi:10.1016/0022-2011(88)90112-7.

[60] R. Triebskorn, H.R. Köhler, T. Zanh, G. Vogt, M. Ludwing, S. Rumpf, M. Kratzmann, G. Alberti and V.S. Torch, Ziet Für Angewandte Zool. 78, 277 (1991).

[61] H.R. Köhler, K. Hüttenrauch, M. Berkus, S. Gräff and G. Alberti, Appl. Soil Ecol. 3, 1 (1996). doi:10.1016/0929-1393(95)00073-9.

[62] D. Raldúa, S. Díez, J.M. Bayona and D. Barceló, Chemosphere 66, 1217 (2007). doi:10.1016/j. chemosphere.2006.07.053.

[63] A.F. Mazon, D.T. Nolan, R.A.C. Lock, M.N. Fernandes and S.E. Wendelaar-Bonga, Toxicol. Vitro 18, 691 (2004). doi:10.1016/j.tiv.2004.03.008.

[64] D.W.T. Au, R.S.S. Wu, B.S. Zhou and P.K.S. Lam, Environ. Pollut. (104), 235. (1999). doi:10.1016/ S0269-7491(98)00176-6.

[65] M.L.S. Mello and R.F. Castilho, in A Célula, edited by H.F. Carvalho and S.M. Recco-Pimentel (Manole, Barueri, Brasil, 2007).

[66] I. Zupan and M. Kalafatic, Bull. Environ. Contam. Toxicol. 70, 688 (2003). doi:10.1007/s00128003-0039-8.

[67] X.M. Liu, J.Z. Shao, L.X. Xiang and X.Y. Chen, Environ. Toxicol. 2180 (2006). doi:10.1002/ tox.20159.

[68] H.U. Riisgard, P.S. Larsen and N.F. Nielsen, Marine Biology. 127, 259 (1996). doi:10.1007/ BF00942111.

[69] H. Silverman, J.W. Lynn and T.H. Dietz, Biol. Bull. 191, 42 (1996). 